\title{
Çok Boyutlu Kurumsal Sürdürülebilirlik Yaklaşımı ile Türk Bankacılık Sektörünün Değerlemesi: Kamu - Özel Banka Farklılaşması*
}

\author{
Evaluation of Turkish Banking Industry based on Multi-Dimensional \\ Corporate Sustainability Model: Comparison between State Owned and \\ Private Banking
}

Güler ARAS', Orcid.org/0000-0002-9438-7191

Nuray TEZCAN², Özlem KUTLU FURTUNA ${ }^{3}$

\begin{abstract}
ÖZET
Kurumlarin farklı açılardan değerlemesi bütünsel performanslarının tam olarak ortaya konulabilmesi açısından önem taşımaktadır. Çalışmada, sürdürülebilirliğin ekonomik, sosyal ve çevresel üç boyutuna ek olarak, yönetsel ve finans boyutları ile birlikte beş boyutlu özgün ve etkin bir kurumsal sürdürülebilirlik yaklaşımı ile bir değerleme yaklaşımı öne sürülmektedir. Bu yaklaşım ile Türk bankacilık sektörünün sürdürülebilirlik değerlemesi kamu ve özel banka farklılaşması kapsamında ortaya konulmustur. Çok boyutlu sürdürülebilirlik yaklaşımı ile 2009-2015 yılları arasında Türk Bankacılık Sektöründe yayınlanan tüm sürdürülebilirlik raporları incelenmiş, belirlenen 139 kriter ile içerik analizi uygulanarak değerleme yapılmıştır. Sürdürülebilir bir bankacılık sisteminin sağlanması ve finansal sistemin daha sağılıklı işlemesini desteklemek amacıyla kamu ve özel sektör bankaları için öneriler sunulmuştur.
\end{abstract}

Anahtar Kelimeler: Kurumsal Sürdürülebilirlik, finansal sistem, bankacılık sektörü, içerik analizi

\section{Gíriş}

Sürdürülebilir kalkınma literatürde çeşitli biçimlerde tanımlanmış olmakla birlikte, en çok bilinen tanımı, Birleşmiş Milletler Çevre ve Kalkınma Komisyonu (World Commission on Environment and Development- WCED) tarafından 1987 yılında yayınlanan "Ortak Geleceğimiz (Our Common Future)" raporunda

\begin{abstract}
In this study, the main indicators of economic, social and environmental and taking into consideration of the governance and financial factors; a fivedimensional, unique and effective corporate sustainability model has been proposed. With this model, corporate sustainability evaluation of Turkish Banking Industry with a comparison between state owned and private banks in Turkey has been evaluated. On the basis of that multidimensional corporate sustainability model, all corporate sustainability reports published in the Turkish Banking Industry between 2009 and 2015 have been examined, and a total of 139 criteria are applied to all reports by utilizing content analysis. Recommendations have been proposed in order to enhance the robustness of the banking in the financial system by comparing corporate sustainability practices of state owned and private banks.
\end{abstract}

Keywords: Corporate Sustainability, financial system, banking industry, content analysis

"Bu çalışma, TÜBITAK 3001 Ar-Ge Projeleri Destekleme Programı kapsamında desteklenen $115 K 708$ Projesi kapsamında yapılmıştır. Çalışmanın içerik analizi kısmında yardımlarından dolayı proje bursiyeri Evrim Hacıoğlu Kazak'a teşekkür ederiz.

'Prof. Dr., Yıldız Teknik Üniversitesi, İşletme Bölümü, Finans Kurumsal Yönetim ve Sürdürülebilirlik Uygulama ve

Araştırma Merkezi (CFGS), dr.guler.aras@gmail.com

${ }^{2}$ Doç. Dr., Haliç Üniversitesi, İşletme Enformatiği Bölümü, nuraytezcan@hotmail.com

${ }^{3} Y r d$. Doç. Dr., Yıldız Teknik Üniversitesi, İşletme Bölümü, Finans Kurumsal Yönetim ve Sürdürülebilirlik Uygulama ve

Araştırma Merkezi (CFGS), ozzlemkutlu@yahoo.co.uk 
genişleyerek sosyal içerikli konuları da kapsamıştır. $\mathrm{Bu}$ noktadan hareketle, sürdürülebilir kalkınmanın çevresel,ekonomik ve sosyal olmak üzere üç temel boyutu bulunmaktadır. Amaç, uzun dönemde bu boyutlar arasında rasyonel bir denge oluşturarak sürdürülebilir kalkınmayı gerçekleştirebilmektir.

Sürdürülebilirlik yaklaşımının işletme düzeyindeki tanımı olan kurumsal sürdürülebilirlik; şirketlerde tüm paydaşlar için uzun vadeli ve kalıcı değer yaratmak amacıyla, ekonomik, çevresel ve sosyal faktörlerin şirket faaliyetlerine ve karar mekanizmalarına uyarlanmasıdır. Illk defa John Elkington (1997) tarafından kullanılan üçlü performans raporlaması (Triple Bottom Line-TBL); kurumsal sürdürülebilirliğin göstergesi olarak ekonomik, sosyal ve çevresel performansın bir arada raporlanmasını ifade etmektedir. Buna göre; ekonomik refah, çevresel kalite ve sosyal alandaki ilerleme birbirini tamamlamalıdır. Biribiri ile ilişkili şekilde iyi yönetilmesi ve dengenin gözetilmesi gereken bu üç alan kurumsal sürdürülebilirliğin vazgeçilmez bileşenleri olarak ve boyutları genişleyerek günümüze kadar gelmiştir.

Sürdürülebilirlik kavramı, bütün işletmeler için önemli olmakla birlikte ekonominin istikrarlı büyümesinde temel rol oynayan finansal kuruluşlar açısından ayrıca önem taşımaktadır. Zira finansal sistemin sağlamlılığı ve sağlıkıı işleyişi bütün ekonomiyi doğrudan etkilemektedir.

Finansal sistem içindeki tasarrufları yatırımlara yönlendirerek sürdürülebilir kalkınmada belirgin bir etki yaratan finansal kuruluşlarının başında ise bankalar gelmektedir. Bankaların iyi yönetilmesi, finansal açıdan güçlülüğü ve sistem içindeki etkinliği aynı zamanda reel sektörün sağlıklı büyümesinin de temel güvencesidir. Sürdürülebilir kalkınmada ve istikrarlı büyümede önemli bir rol oynayan bankaların, sürdürülebilir yatırımları finanse etmek ve müşterilerini de bu konuda bilinçlendirmek konusunda duyarlııklarının, diğer sektörlere göre son yıllarda önemli ölçüde arttığı gözlemlenmektedir (Jeucken 1999: 22). Bunun da ötesinde, bankaların artık hissedar yaklaşımından paydaş yaklaşımına doğru yönelmeleri, karar süreçlerinde basiretli ve uzun vadeli hedeflere yönelik hareket ederek sürdürülebilir performans hedeflerine odaklanmaları artık çok daha önemli hale gelmiştir.

Bununla birlikte; son küresel ekonomik gelişmeler, kurumsal sürdürülebilirliğin temel göstergeleri olan ekonomik, sosyal ve çevresel performansın şirketlerin sürdürülebilirlik uygulamaları için artık tek başına yeterli olmadığını göstermiştir. Bu göstergeler ile birlikte, iyi bir yönetsel yapı, kurumsal yönetim ve finansal göstergelerin sağlamlığı, kurumsal sürdürülebilirliği tamamlayan faktörler olarak karşımıza çıkmaktadır. $\mathrm{Bu}$ durum, temel sürdürülebilirlik faktörlerinin yanında yönetsel ve finansal faktörlerin de firmaların sürdürülebilirlik performansının ölçümünde dikkate alınmasını gerekli hale getirmiştir (Aras, 2015:29). Diğer taraftan, finansal performans ile sosyal ve çevresel performans arasında bir çatışma olduğu görülmektedir. Bununla birlikte, iyi bir finansal performansın, gelecekte çevresel ve sosyal boyutta da iyi bir performans yaratacağı dikkate alındığında bu bakış açısının gerçeği tam olarak yansıtmadığı anlaşılmaktadır (Aras ve Crowther, 2009: 4).

$\mathrm{Bu}$ çalışma sürdürülebilirliği ekonomik, sosyal, çevresel, yönetsel ve finansal olmak üzere beş farklı boyutu ile kapsamlı olarak değerleyen ilk özgün çaıışma özelliği taşımaktadır. Sürdürülebilirliğin ekonomik, sosyal ve çevresel üç boyutuna ek olarak yönetim ve finans boyutları ile birlikte, Şekil 1'de görülen beş boyutlu özgün ve etkin bir kurumsal sürdürülebilirlik modeli öne sürülmektedir.

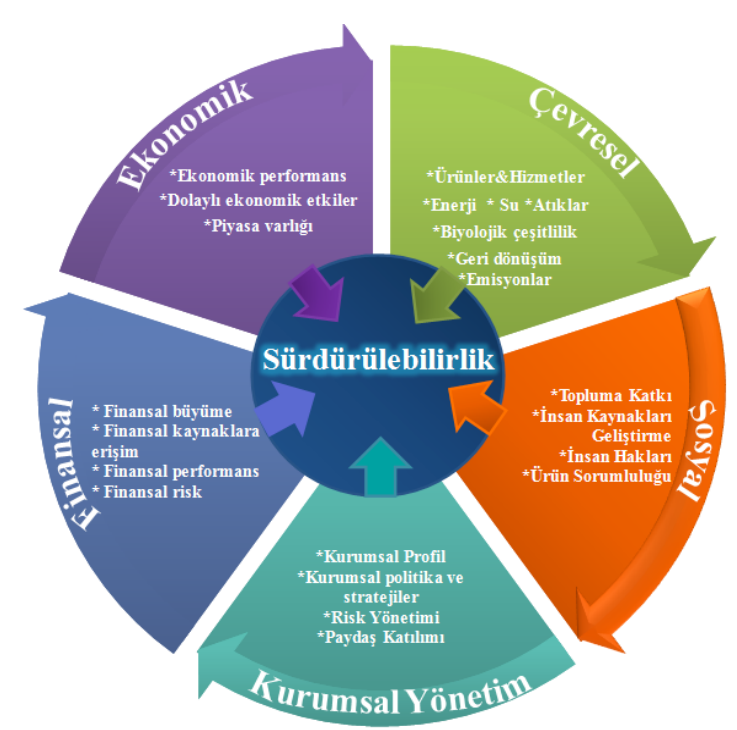

Şekil 1: Çok Boyutlu Kurumsal Sürdürülebilirlik Modeli

Çalışmanın ikinci bölümünde konu ile ilgili literatür anlatılacak, üçüncü bölümde ise; sırasıyla araştırmanın kapsamı ve yöntemi hakkında bilgi verilerek, içerik analizi ile elde edilen bulgular açıklanacaktır. Sonuç bölümünde ise bankaların kurumsal sürdürülebilirlik göstergeleri değerlendirilerek önerilere yer verilecektir. 


\section{KURUMSAL SÜRDÜRÜLEBILIRLIK ÖLÇÜMÜ KONUSUNDA YAPILAN ÇALIŞMALAR}

Literatürde kabul görmüş bir ölçüm şekli olmaması nedeniyle, sürdürülebilirlik raporlaması alanında iki önemli uluslararası endeks yapılan çalışmalarda gösterge olarak kabul edilmektedir. Dow Jones Sürdürülebilirlik Endeksleri (Dow Jones Sustainability Indices-DJSI) ve Küresel Raporlama Girişimi (Global Reporting Initiative-GRI) adı verilen bu endeksler dışında yerel olarak birçok farklı araştırma gerçekleştirilmiştir. Bu çalışmaların bazılarında tamamen sayısal verilerle ölçüm yapılmış, bazılarında ise, anket, saha çalışması ve mülakat yapılarak elde edilen veriler sayısallaştırılıp ölçüm yapılmaya çalışılmıştır.

Ranganatan (1998), çalışmasında şirketlerin sosyal, çevresel ve ekonomik performanslarının hangi göstergelerle ölçülmesi gerektiği üzerinde durmuştur. Bu göstergelerin; rekabet avantajı, çevresel yönetim sistemleri, tedarik zinciri, kredi ve yatırım olanakları, hissedar beklentileri, uluslararası standartlar, inovasyon çabaları, rekabet baskısı ve raporlama çalışmaları olduğunu belirtmiştir. Bu kriterlerden yola çıkarak, üçlü bir şema oluşturulmuş ve sosyal, ekonomik ve çevresel göstergelerin birbiriyle bağlantılı olması gerektiği sonucu elde edilmiştir. Bununla birlikte çevresel ve sosyal göstergelerin ölçümünde zorluklar olduğuna dikkat çekilmiştir.

Moneva vd. (2007: 95) ise İspanya Madrid Borsası'nda işlem gören 52 işletmenin sürdürülebilirlik raporlarının kalitesi ve GRI raporlama standartlarını kullanıp kullanmamalarına göre bir ölçek oluşturarak işletmeleri bu ölçeğe göre konumlandırmış ve ölçekte üst sıralarda yer alan işletmelerin finansal performansının da olumlu yönde etkilendiğini gözlemlemişlerdir.

Aras ve Crowther (2009a), Türkiye'de finans sektörü dışında kalan halka açık bütün firmaları kapsadıkları araştırmalarında sürdürülebilirlik performanslarının aslında firma ölçeği ile yakın ilişki içinde olduğunu bulmuşlardır. Firma ölçeği büyüdükçe açıklama yapma düzeyinin ve sürdürülebilirlik uygulama etkinliğinin arttığını göstermişlerdir.

Khan vd. (2011: 357), 2008-2009 yıllarında GRI G3 kılavuzuna göre raporlama yapan Dhaka Borsasında işlem gören 12 bankanın sürdürülebilirlik uygulamalarını, içerik analizi yöntemini kullanarak analiz etmişlerdir. Bankaların, çevre, insan kaynakları, ürün sorumluluğu, insan hakları ve sosya boyutlarına ilişkin kurumsal sürdürülebilirlik göstergeleri içinde en çok sosyal sürdürülebilirlik konusunda açıklama yapıldığını tespit etmişlerdir. Ürün sorumluluğu ve insan hakları boyutlarında yapılan açıklamaların ise en az açıklama yapılan boyutlar olduğunu belirtmişlerdir.

Sobhani vd. (2009: 177) yılı çalışmasında, hem Dhaka Borsası hem de Chittagong Borsasında işlem gören 100 şirketin yıllık raporlarını kurumsal, sosyal ve çevresel açıklamalar yönünden içerik analizi ile incelemişler ve genel olarak açıklamaları yetersiz bulmuşlardır. Sobhani vd.'nin (2012: 83) yaptığı diğer bir çalışmada ise, 29 Bangladeş bankasına ait kurumsal sürdürülebilirlik göstergeleri analiz edilmiştir. Çalışmada, cevresel, ekonomik ve sosyal sürdürülebilirlik boyutlarına ilişkin GRI raporları ve anket sonuçları doğrultusunda elde edilen kriterleri araştırarak, bankaların en çok sosyal boyuta ilişkin açıklama yaptıklarını tespit etmişlerdir.

Geleneksel ve islami bankacilık uygulamalarının karşılaştırıldığı bir başka çalışma ise Nobanee ve Ellili (2016) çalışmasıdır. Bu çalışmada, Dubai ve Abu Dhabi borsasında işlem gören 16 bankanın 2003-2013 dönemine ait sürdürülebilirlik raporlarından yola çıkılarak sürdürülebilirlik boyutlarına ilişkin analizler yapılmıştır. Illgili dönemde geleneksel bankaların islami bankalara göre daha çok açıklama yaptıkları görülmüştür.

Hussain, Rigoni ve Orij (2016) çalışmalarında kurumsal yönetim ve sürdürülebilirlik performansı arasında ilişkiyi araştırmış ve Amerika'daki işletmelerin sürdürülebilirlik performanslarının ölçümü için sürdürülebilirlik raporlarının üçlü performans raporlaması çerçevesinde ekonomik, sosyal ve çevresel boyutlarda içerik analizleri yapmışlardır.

Weber (2016), çalışmasında ise Çin'deki bankaların sürdürülebilirlik performanslarını analiz ederek, bu bankaların sürdürülebilirlik performansları ile finansal göstergeleri arasındaki ilişkiyi araştırmıştır. Analiz sonucunda, sürdürülebilirlik performansının finansal göstergelerden toplam varlıklar ve net kar ile güçlü bir ilişki içerisinde olduğu tespit edilmiştir.

Türkiye'den örneklere bakıldığında ise finansal hizmetler sektöründe kurumsal sürdürülebilirlik konusunda çok az akademik çalışmanın olduğu görülmektedir. Kaya (2010: 83-84), sürdürülebilir kalkınma sürecinde Türk bankaların rolünü araştırdığı çalışmasında, gelişmekte olan ülkelerde sürdürülebilir finans anlayışının gelişmesine engel olan nedenlerin yasal düzenlemelerin eksikliği, istikrarsız sürdürülebilir 
kalkınma politikaları, finansal kuruluşların sürdürülebilir finansa ilişkin bilgi yetersizliği ve toplumun sürdürülebilir kalkınma konusundaki bilinç eksikliği olarak belirtmiştir.

Özçelik ve Öztürk'ün (2014) çalışmasında üç özel bankanın 2011 yılı sürdürülebilirlik raporlarından ekonomik, çevresel ve sosyal performanslarına ilişkin oranlar üç finansal, iki sosyal ve dört çevresel oran grubunda toplanarak, sürdürülebilirlik performansları Grey ilişkisel analizi ile araştırılmıştır. Analiz sonuçlarına göre, sürdürülebilirlik performansı açısından öne çıkan bankalar sıralanmıştır. Bir diğer Türk Bankacılık Sektörüne ait çalışma ise Kaderli ve Gündüz (2014)'e aittir. Sadece tek bir bankanın sürdürülebilirlik raporlarındaki verilerinden hareketle sürdürülebilirlik performansı ve finansal performans arasındaki ilişki değerlendirilmiştir. Analizler sonucunda, sürdürülebilirlik raporlarındaki bilgilerle finansal oranlar arasında olumlu ilişkiler tespit edilmekle birlikte, bu ilişkinin şiddeti çok güçlü bulunamamıştır.

\section{KAMU VE ÖZEL SEKTÖR BANKALARINDA SÜRDÜRÜLEBILIRLIK RAPORLARININ IÇERIK ANALIZi YÖNTEMI İLE DEĞERLENDIRILILESI}

Çalışmada, bankacılık sektöründe sürdürülebilirlik uygulamalarının yıllar itibarıyla değişimi ve gelişimi, kamu ve özel bankalar farklılaşması temelinde araştırılmaktadır. Türkiye'de faaliyet gösteren bankalarda, henüz mevzuata geçmemiş sürdürülebilirlik uygulamaları temel bankacılık uygulamaları ile birlikte banka yönetiminin yaklaşımına, bu konudaki bilincine ve uygulama isteğine bağlı olarak bankalar arasında önemli farklılıklar göstermektedir. Bu çerçevede bankanın kamu ve özel statüde olmasının bu farklılaşmayı etkileyecek önemli faktörler arasında olduğu uluslararası literatürde tespit edilen bir bulgudur. Burada kamu bankalarının sermaye kaynağının kamu olmasından kaynaklı sosyal ve çevresel sorumluluk bilincininin daha yüksek olması gereği ve beklentisi, gerçekte bankaların bu alandaki değerlemelerine ne kadar yansıyacağı hep merak konusu olmuştur. Bu çalışma Türk bankacılık sektörü açısından bu durumu tespit etmeyi amaçlamaktadır.

\subsection{Araştırma Kapsamı}

Araştırmanın kapsamını, 2009-2015 yılları arasında Türk Bankacılık sektöründe sürdürülebilirlik raporlaması yapan tüm bankalar oluşturmaktadır. Araştırmada bankacılık sektörünün seçilmesinin birden fazla sebebi bulunmaktadır. Temel neden, bankacılık sektörünün sürdürülebilirlik performansının reel sektörü, finans piyasalarının bütününü ve ekonomiyi doğrudan etkileyebilme ve yönlendirme gücüne sahip olmasıdır. Bu noktadan hareketle, bankaların sürdürülebilir yatırımları finanse etmek ve müşterilerini de bu konuda bilinçlendirmek konusunda daha duyarlı olmaları gerektiğinin anlaşılmasıyla birlikte bankaların yayınladığı sürdürülebilirlik raporlarının son derece önem kazandığı görülmektedir (Aras, 2015:2). Bankacılık sektörü üzerinde çalışılmasının ikinci nedeni, sektör bazında kurumsal sürdürülebilirlik raporlarının dağılımına bakıldığında, en fazla rapor yayınlayan sektörün bankacılık sektörü olmasıdır. Son olarak, Haziran 2016 itibariyle 29 şirketin yer aldığı Borsa İstanbul Sürdürülebilirlik Endeksi'nde ağırlıklı olan sektörün, 6 banka ile bankacılık sektörü olmasıdır. Araştırma kapsamında, 3 kurumsal sürdürülebilirlik raporu ile 2 kamu bankası ve 24 kurumsal sürdürülebilirlik raporu ile 7 özel banka, toplamda 27 kurumsal sürdürülebilirlik raporu ile 9 banka yer almaktadır. Mevduat bankaları içinde ilk kurumsal sürdürülebilirlik raporunun Akbank tarafından 2009 yılında yayınlanmış olması nedeni ile araştırma dönemi 2009-2015 ilk çeyrek olarak belirlenmiştir. Tablo 1, araştırma kapsamında kamu ve özel bankacılık sektörü tarafından yayınlanan sürdürülebilirlik raporlarının dağılımını göstermektedir. Türkiye'de, mevduat bankaları içinde ilk kurumsal sürdürülebilirlik raporunu yayınlayan Akbank'ın, düzenli bir şekilde yayınlamaya devam ettiği görülmektedir.

\subsection{Kurumsal Sürdürülebilirlik Göstergelerinin Belirlenmesi}

Çalışmada, GRI Raporlama Çerçevesi, Birleşmiş Milletler Çevre Programı Finans Girişimi (UNEP FI) literatür taraması sonuçları (Sobhani, 2012: 83-85) ve üst düzey yöneticiler ile gerçekleştirilen mülakatlar sonucunda, Türk Bankacılık Sektörü'ne özgü, Ekonomik, Finansal, Çevresel, Sosyal ve Yönetsel olmak üzere 5 boyutu temsil eden toplamda 139 Kurumsal Sürdürülebilirlik kriteri belirlenmiştir. Belirlenen 139 sürdürülebilirlik kriterinin boyutlara göre dağılımı Şekil 2'de belirtilmektedir. Çevresel göstergeler, enerji tüketimi ve tasarruf ile doğal çevre alt kriterlerinden; sosyal göstergeler ise topluma katkı, insan kaynakları, insan hakları ve ürün sorumluluğu alt kriterlerinden oluşmaktadır. 


\subsection{Araştırma Yöntemi}

Çalışmada yöntem olarak, İçerik Analizi kullanılmıştır. Bu yöntem, bir ya da birden fazla metinde belirli kelime ya da kavramların varlığını belirlemek için kullanılan bir yöntemdir. Weber (1990: 20), içerik analizini kısaca "metinden geçerli çıkarımlar yapmak için uygulanan bir dizi prosedür", Krippendorff (2004: 18) ise "metinlerden geçerli çıkarsamalar yapmak için bir araştırma tekniği" olarak tanımlamıştır. Içerik analizi, söylemin görünen, kolayca yakalanan, sergilenmiş ve ilk bakışta algılanan içeriği yerine, gizil, üstü örtülü içeriğini ortaya çıkarmak için kullanılan bir yöntemdir (Bilgin, 2006: 1). Yöntemde araştırmacı, araştııılan kelime ve kavramları sayısallaştırır, analiz eder ve metinde verilen mesaj hakkında çıkarımlarda bulunur. Analiz edilecek olan metin; kitap, kitapta bölüm, makale, mülakat, tartışmalar, gazete başlıkları, tarihi belgeler, konuşmalar, reklam olabilir.
Literatürde, metinde yapılan açıklamaların miktarının sayfa sayısı, kelime sayısı (Ng,1985) veya cümle sayısı (Hackson ve Milne 1996) olarak ifade edilmesi gerektiği şeklinde farklı görüşlerin olduğu görülmektedir. Milne ve Adler (1999: 240) cümleleri bir kodlama aracı olarak kullanmanın, diğer analiz birimlerinden çok daha güvenilir olduğunu, kelimeler kullanıldığında güvenilmezliğin arttığını belirtmişlerdir. Raporlardaki sürdürülebilirlik açıklamaları, içerdikleri cümle sayıları baz alınarak sayısallaştırılmakta (Hackston ve Milne, 1996: 84; Sobhani, 2012: 80), bu doğrultuda, her bir göstergeyi temsil eden açıklamaların içerdiği toplam cümle sayısı, o göstergenin kriter değerini oluşturmaktadır. Bu aşamada, bankanın raporlarında yer alan kurumsal sürdürülebilirlik açıklamalarının hangi göstergelerde yoğunlaştığı ortaya çıkmakta ve yıllar itibariyle yapılan açıklamalardaki (boyut, kriter bazlı) değişim, dönüşüm ve gelişmeler izlenmektedir.

Tablo 1: Kamu ve Özel Bankalara ait Kurumsal Sürdürülebilirlik Raporlarının Dağılımı

\begin{tabular}{|c|c|c|}
\hline & Raporlama Dönemi & Raporlama Kılavuzu \\
\hline \multicolumn{3}{|l|}{ Kamu Bankaları } \\
\hline Vakıfbank & 2014-2015 & GRI G4 \\
\hline \multirow{2}{*}{ Ziraat Bankası } & 2013 & GRI G3.1 \\
\hline & 2014 & GRI G4 \\
\hline Halkbank & $2013^{1}$ & GRI G4 \\
\hline \multicolumn{3}{|l|}{ Özel Bankalar } \\
\hline \multirow{7}{*}{ Akbank } & 2009 & GRI G3 \\
\hline & 2010 & GRI G3 \\
\hline & 2011 & GRI G3 \\
\hline & 2012 & GRI G3 \\
\hline & 2013 & GRI G3 \\
\hline & 2014 & GRI G4 \\
\hline & $2015^{2}$ & GRI G4 \\
\hline \multirow{5}{*}{ Garanti Bankası } & 2010 & GRI değil ${ }^{3}$ \\
\hline & 2011-2012 & GRI G3.1 \\
\hline & 2013 & GRI G4 \\
\hline & 2014 & GRI G4 \\
\hline & $2015^{2}$ & GRI G4 \\
\hline \multirow{3}{*}{ İş Bankası } & 2012 & GRI G3.1 \\
\hline & 2013 & GRI G3.1 \\
\hline & 2014 & GRI G3.1 \\
\hline Şekerbank & 2013 & GRI G3.1 \\
\hline \multirow{4}{*}{ TSKB } & $2008-2009$ & GRI G3 \\
\hline & 2009-2010 & GRI G3 \\
\hline & 2011-2012 & GRI G3.1 \\
\hline & 2013-2014 & GRI G4 \\
\hline Türkiye Finans Bankası & 2013 & GRI G3 \\
\hline \multirow{5}{*}{ Yapı Kredi Bankası } & 2010 & GRI değil ${ }^{3}$ \\
\hline & 2011 & GRI değil ${ }^{3}$ \\
\hline & 2012 & GRI değil ${ }^{3}$ \\
\hline & 2013 & GRI G3.1 \\
\hline & 2014 & GRI G4 \\
\hline
\end{tabular}


Çalışmada, içerik analizi NVivo 11.0 Pro nitel veri analizi paket programı ile üç araştırmacı tarafından gerçekleştirilmiştir. Türk Bankacılık Sektörü'ne özgü kurumsal sürdürülebilirlik kriterlerinin listesi, Ek 1 de yer almaktadır.

\subsection{Araştırma Bulguları}

Çalışmanın ilk aşamasında, yıllar itibariyle kurumsal sürdürülebilirlik raporlarındaki açıklama sayılarındaki değişim açıklanmaya çalışılmıştır. Bu bağlamda, Türk Bankacılık Sektörü'nde yayınlanan sürdürülebilirlik raporlarından ilgili kriterler göz önüne alınarak elde edilen açıklama sayılarının temel boyut bazında yıllar itibariyle değişimi Şekil 3'de yer almaktadır.

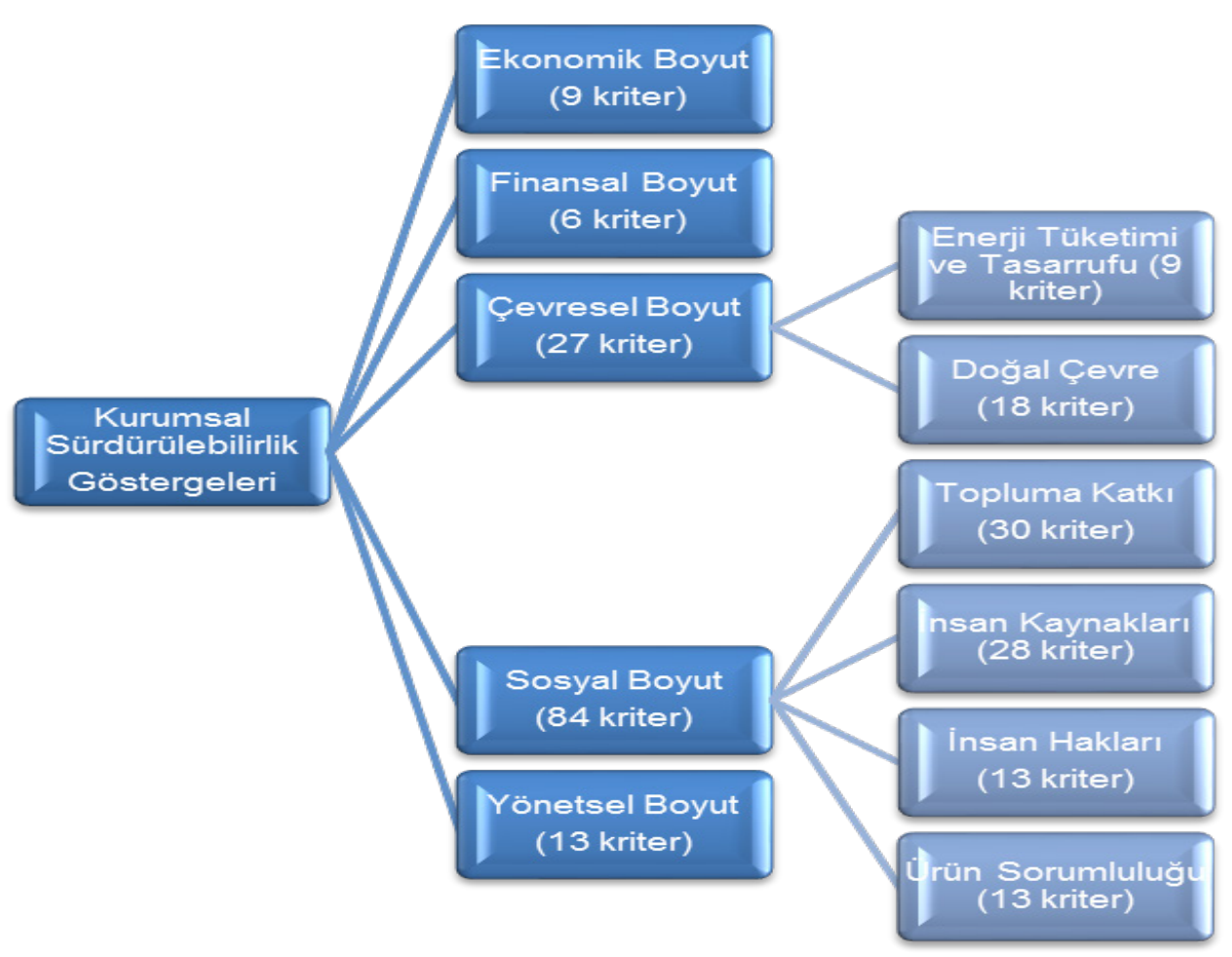

Şekil 2: Kurumsal Sürdürülebilirlik Kriterlerinin Boyutlara Göre Dağılımı

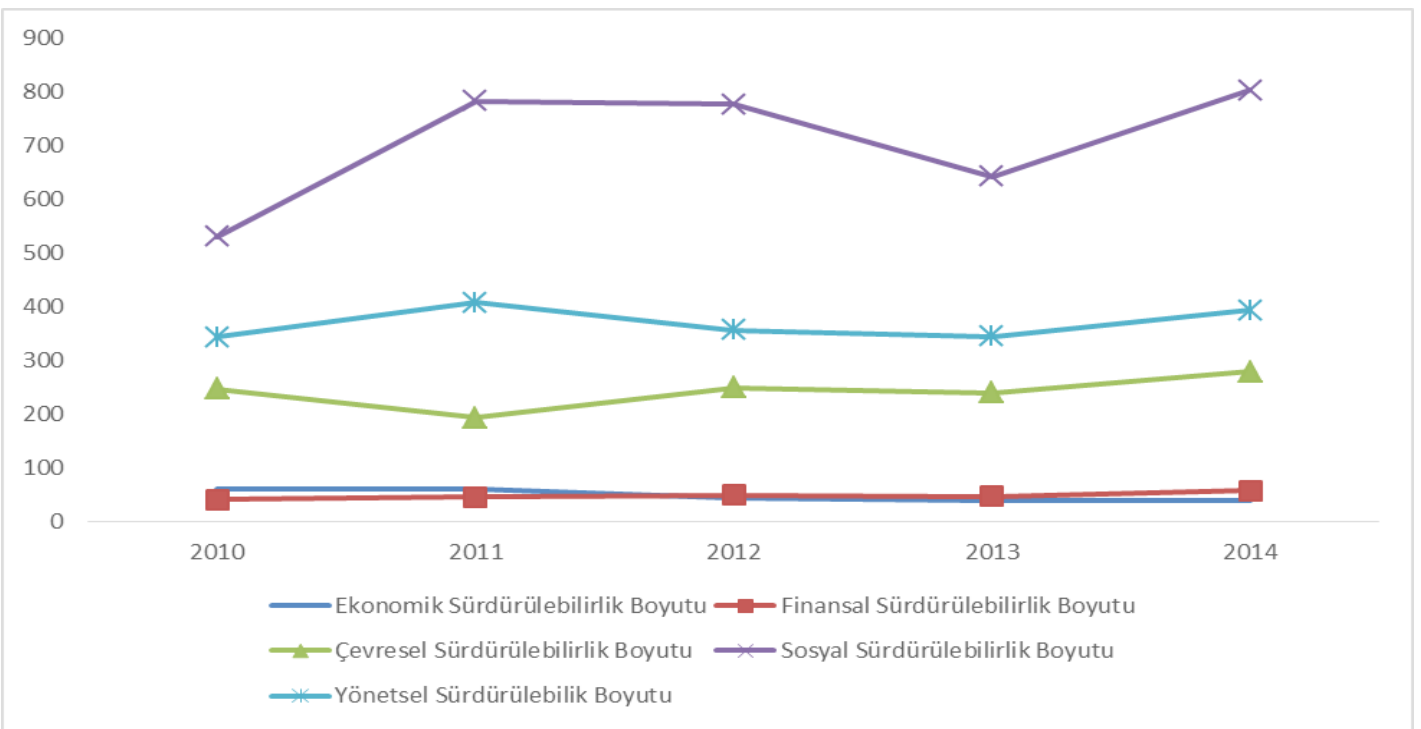

Şekil 3: Temel Boyut Bazında Kurumsal Sürdürülebilirlik Açıklamalarının Yıllar İtibariyle Değişimi 
2009 yılında, yalnızca Akbank ve TSKB'nin ve 2015 yılı ilk çeyrek sonu itibariyle yalnızca Vakıfbank'ın kurumsal sürdürülebilirlik raporlarının yayınlanmış olması nedeniyle 2009 ve 2015 yıllarına ilişkin ortalama değerler sektörü temsil etmeyeceği için kapsam dışında bırakılmıştır. 2010-2014 yıllarına ilişkin göstergeler ise bankaların ortalama değerlerinden elde edilmiştir.

Şekil 3 incelendiğinde, araştırma döneminde yıllar itibariyle bankaların en çok sosyal sürdürülebilirlik boyutu ile ilgili açıklama yaptıkları görülmektedir. En az açıklama yapılan boyutlar ise ekonomik ve finansal boyutlardır. 2014 yılında, sektörde yer alan tüm kurumsal sürdürülebilirlik raporlarında beş boyutu temsil eden sürdürülebilirlik göstergelerinin daha çok açıklandığını söylemek mümkündür.

Araştırma kapsamında incelenen kamu ve özel bankalarının sürdürülebilirlik raporlarından elde edilen açıklamalara ait tanımsal istatistikler Tablo 2'de verilmektedir. Bankalar tarafından yayınlanan raporların karşılaştırılabilir olması için, her bir temel ve alt boyuta ait açıklamaların toplam içindeki yüzdesi alınmıştır.

Tablo 2 incelendiğinde, ekonomik ve finansal boyutlarda kamu ve özel bankalarının açıklama ortalamaları birbirine yakın değerlerde olup, çevresel ve sosyal boyutlarda kamu bankalarının özel bankalardan çok az bile olsa daha yüksek ortalamaya sahip olduğu, yönetsel boyutta ise, özel bankaların belirgin şekilde daha yüksek ortalamaya sahip olduğu görülmektedir. Özel bankalar grubunda banka ve rapor sayısı daha fazla olduğu için, tüm temel ve alt boyutlarda en küçük ve en büyük değerler arasındaki fark diğer bir ifade ile aralık daha geniş olmakta ve buna bağlı olarak değişkenlik göstergesi olan standart sapma da daha büyük olarak elde edilmektedir.

Şekil 4'de kamu ve özel bankaların sürdürülebilirlik göstergeleri, temel boyut bazında yüzde olarak verilmekte ve böylelikle farklılaşma ortaya konmaktadır. Tablo 2'de alt boyutlara ve Şekil 4'de temel boyutlara ait sonuçlar birlikte değerlendirildiğinde aşağıdaki sonuçlara ulaşmak mümkündür.

Ekonomik sürdürülebilirlik boyutunda, özel bankaların en çok açıklama yaptıkları ilk üç göstergenin sırasıyla Yerli Ekonomideki Yeri, Ulusal Hazineye Katkısı ve Altyapısal ve Kurumsal Gelişim olduğu belirlenmiştir. Kamu bankalarında ise, en çok açıklama yapılan ilk üç göstergenin sırasıyla Yerli Ekonomideki Yeri, Altyapısal ve Kurumsal Gelişim ve Ekonomik Katkı Raporu olduğu görülmektedir. Bu bağlamda, her iki banka grubunda da yıllar itibariyle en çok açıklama yapılan ekonomik sürdürülebilirlik boyutunun bankaların Yerli Ekonomideki Yeri açıklamaları olduğu dikkati çekmektedir. Illgili boyutta, özel bankalar grubunda en az açıklama yapılan göstergelerin ise sırasıyla Diğer Ekonomi Açılamaları ve Dağıtılmayan Karlar Hakkında Bilgi olduğu görülmektedir. Dağıtılmayan karlar hakkında bilgi açıklaması yapan tek bankanın ise TSKB olduğu dikkati çekmektedir. Kamu bankalarında ise özel bankalara göre, bu boyutta daha az açıklama yapıldığı görülmektedir. Dağıtılmayan Karlar Hakkında Bilgi, Sermaye Sahiplerine Yapılan Ödemeler, Kurumsal Sosyal Sorumluluk ve Sürdürülebilirlik Çalışmalarına Harcanan Miktar ve Diğer Ekonomi Açıklamaları kriterlerinde kamu bankalarının açıklama yapmadıkları görülmüştür.

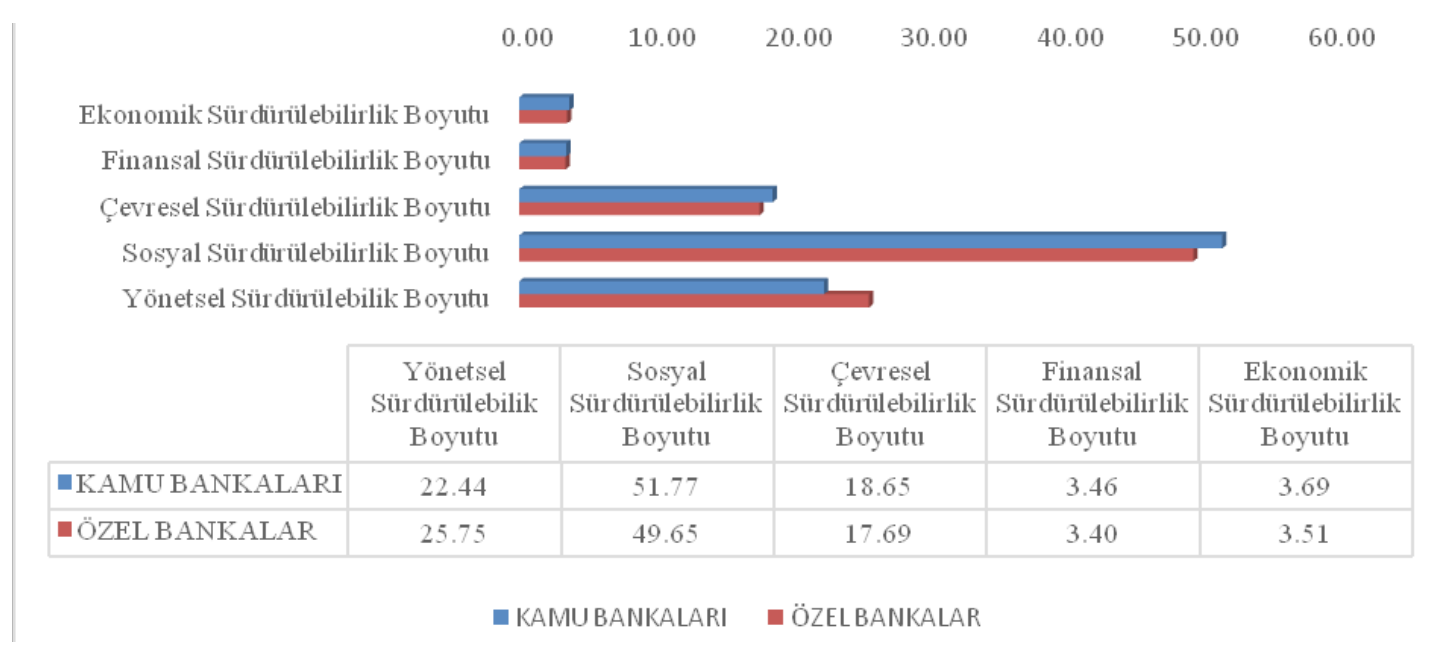

Şekil 4: Kamu ve Özel Banka Sürdürülebilirlik Göstergelerinin Farklılaşması (\%) 


\begin{tabular}{|c|c|c|c|c|c|c|c|c|c|c|c|c|}
\hline \multirow{6}{*}{ 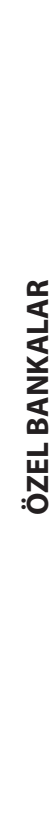 } & 高 & $\stackrel{\mathbb{N}}{ }$ & $\stackrel{\mathbb{N}}{ }$ & $\stackrel{\mathbb{N}}{ }$ & $\stackrel{\Xi}{\sim}$ & $\stackrel{\Xi}{\sim}$ & $\stackrel{ \pm}{N}$ & $\stackrel{\Xi}{\sim}$ & $\stackrel{\Xi}{\sim}$ & $\stackrel{\Xi}{\sim}$ & $\stackrel{\Xi}{\sim}$ & ন \\
\hline & 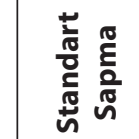 & $\stackrel{m}{\stackrel{m}{i}}$ & $\stackrel{\text { mે }}{-}$ & $\begin{array}{l}\infty \\
\substack{\infty \\
0 \\
0}\end{array}$ & $\underset{\text { ָे }}{\text { i }}$ & مे & $\stackrel{m}{\stackrel{m}{*}}$ & $\stackrel{\text { ำ. }}{\wedge}$ & $\stackrel{\check{\sigma}}{\check{+}}$ & $\stackrel{?}{\stackrel{-}{\leftarrow}}$ & $\begin{array}{l}\hat{\imath} \\
\hat{0}\end{array}$ & 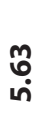 \\
\hline & $\begin{array}{l}\frac{n}{n} \\
\sum\end{array}$ & סo & $\frac{n}{r}$ & $\frac{\mathfrak{N}}{\mathfrak{m}}$ & గ్ & 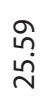 & $\begin{array}{c}\hat{m} \\
\stackrel{m}{n}\end{array}$ & $\begin{array}{l}\text { on } \\
\stackrel{n}{n}\end{array}$ & $\begin{array}{l}\hat{\alpha} \\
\infty \\
\infty\end{array}$ & $\underset{i n}{\stackrel{0}{n}}$ & $\begin{array}{l}m \\
\infty \\
\stackrel{\infty}{0} \\
\text { D. }\end{array}$ & 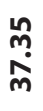 \\
\hline & $\stackrel{\underline{\Xi}}{\Sigma}$ & $\stackrel{\text { n̊ }}{-}$ & $\stackrel{\text { ঙํ }}{\text { ஸे }}$ & $\begin{array}{l}\bar{\delta} \\
\infty \\
\infty\end{array}$ & $\stackrel{\infty}{i}$ & 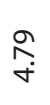 & $\begin{array}{l}\hat{N} \\
\text { ஸे } \\
\text { Non }\end{array}$ & $\stackrel{1}{6}$ & $\stackrel{\infty}{\stackrel{\infty}{m}}$ & $\stackrel{8}{0}$ & $\stackrel{\mathbb{N}}{\underset{\sim}{*}}$ & $\begin{array}{l}\text { フ̃ } \\
\dot{+}\end{array}$ \\
\hline & 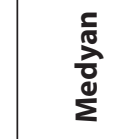 & 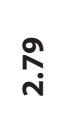 & $\begin{array}{l}\stackrel{8}{0} \\
\dot{m}\end{array}$ & 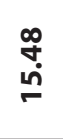 & $\stackrel{P}{\stackrel{+}{+}}$ & $\begin{array}{l}\text { Do } \\
\stackrel{0}{0} \\
0\end{array}$ & $\begin{array}{l}\text { ஃ } \\
\text { qे }\end{array}$ & $\begin{array}{l}\stackrel{\Xi}{ } \\
\dot{ \pm}\end{array}$ & $\frac{a}{\check{ \pm}}$ & $\stackrel{\sim}{\sim}$ & $\begin{array}{l}\text { \&̊. } \\
\stackrel{0}{\sigma}\end{array}$ & $\begin{array}{l}\text { ஸุ } \\
\text { ஸे }\end{array}$ \\
\hline & $\begin{array}{l}\dot{ \pm} \\
\dot{ \pm} \\
\dot{z}\end{array}$ & $\underset{m}{\bar{n}}$ & $\underset{m}{\stackrel{+}{+}}$ & $\begin{array}{l}\text { ํㅜ } \\
\stackrel{1}{0}\end{array}$ & $\stackrel{n}{\stackrel{n}{i n}}$ & $\stackrel{\stackrel{\sim}{\sim}}{\underset{N}{N}}$ & $\begin{array}{l}n \\
0 \\
o \\
\dot{q}\end{array}$ & $\begin{array}{l}\stackrel{\infty}{0} \\
\stackrel{\sigma}{0}\end{array}$ & 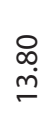 & $\bar{n}$ & $\stackrel{\stackrel{2}{N}}{\stackrel{-}{-}}$ & $\begin{array}{l}\stackrel{n}{\hat{~}} \\
\text { ஸे }\end{array}$ \\
\hline \multirow{6}{*}{ 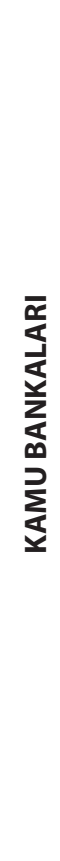 } & 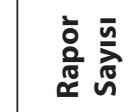 & $m$ & $m$ & $m$ & $m$ & $m$ & $m$ & $m$ & $m$ & $m$ & $m$ & $m$ \\
\hline & 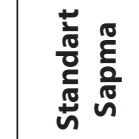 & 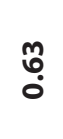 & $\frac{n}{0}$ & ò & $\stackrel{m}{\text { mo }}$ & $\underset{\sim}{\stackrel{\sigma}{*}}$ & $\underset{\sim}{\stackrel{\sim}{+}}$ & $\stackrel{\text { }}{r}$ & $\stackrel{m}{\leftarrow}$ & $\stackrel{\widehat{o}}{-}$ & 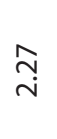 & $\stackrel{n}{\hat{i}}$ \\
\hline & $\frac{\tilde{y}}{\sum}$ & $\begin{array}{l}\stackrel{\text { mे }}{\dot{r}} \\
\text { }\end{array}$ & $\begin{array}{l}n \\
\dot{m} \\
\dot{m}\end{array}$ & $\begin{array}{l}\overline{0} \\
\stackrel{0}{0}\end{array}$ & 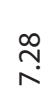 & 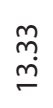 & $\begin{array}{l}0 \\
0 \\
\text { in }\end{array}$ & $\begin{array}{l}\stackrel{\omega}{\alpha} \\
\infty \\
\infty\end{array}$ & $\begin{array}{l}\stackrel{n}{N} \\
\stackrel{n}{n}\end{array}$ & 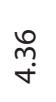 & $\begin{array}{l}\stackrel{+}{\sim} \\
\dot{\sim}\end{array}$ & $\stackrel{\infty}{\dot{n}}$ \\
\hline & $\stackrel{\underline{\Sigma}}{\Sigma}$ & $\frac{\circ}{\dot{m}}$ & $\underset{m}{\stackrel{m}{m}}$ & $\begin{array}{l}\infty \\
\stackrel{0}{0} \\
\dot{0}\end{array}$ & 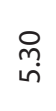 & 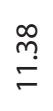 & ํㅜㅇ & 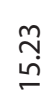 & 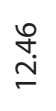 & $\stackrel{\text { Ln }}{-}$ & $\begin{array}{l}\hat{0} \\
\dot{0}\end{array}$ & $\begin{array}{l}\hat{\circ} \\
\circ\end{array}$ \\
\hline & 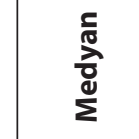 & $\begin{array}{l}\bar{n} \\
m \\
m\end{array}$ & $\underset{\text { m }}{\tilde{y}}$ & \begin{tabular}{l}
$\stackrel{0}{0}$ \\
$\infty$ \\
\hdashline
\end{tabular} & $\begin{array}{l}\infty \\
\stackrel{\infty}{n} \\
\text { in }\end{array}$ & $\begin{array}{l}\stackrel{\infty}{\infty} \\
\stackrel{\sim}{\sim}\end{array}$ & $\begin{array}{l}\hat{m} \\
\text { aे }\end{array}$ & $\frac{1}{6}$ & $\stackrel{\stackrel{\sim}{\sim}}{\stackrel{m}{n}}$ & $\frac{O}{m}$ & $\begin{array}{l}\stackrel{\infty}{\infty} \\
\stackrel{-}{\perp}\end{array}$ & 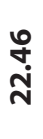 \\
\hline & 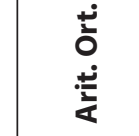 & $\begin{array}{l}\text { Oे } \\
\text { in }\end{array}$ & 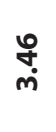 & $\begin{array}{l}n 0 \\
0 \\
\infty \\
\infty\end{array}$ & $\frac{m}{\sigma}$ & 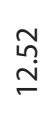 & $\frac{\widehat{T}}{i n}$ & $\begin{array}{l}\stackrel{\infty}{\hat{\omega}} \\
\stackrel{0}{0}\end{array}$ & $\begin{array}{l}\dot{J} \\
\stackrel{M}{ }\end{array}$ & $\underset{\sim}{\mathbb{\infty}}$ & $\begin{array}{l}0 \\
\stackrel{1}{0} \\
\infty\end{array}$ & 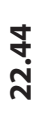 \\
\hline \multicolumn{2}{|c|}{ 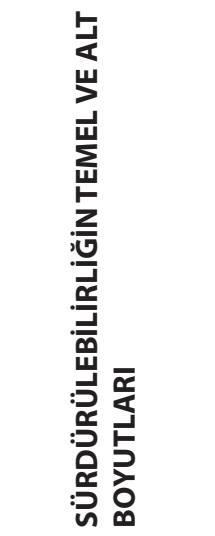 } & 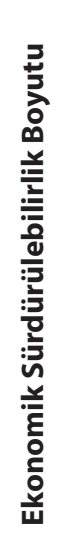 & 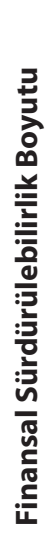 & 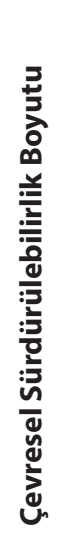 & 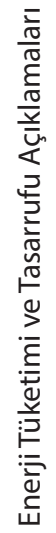 & 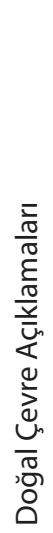 & 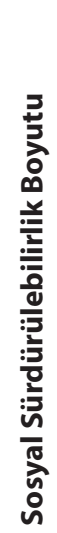 & 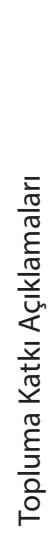 & 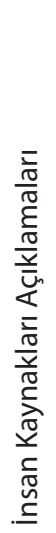 & 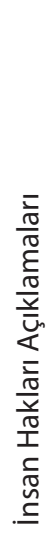 & 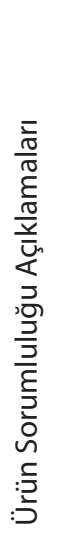 & 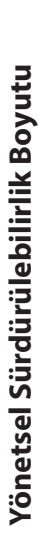 \\
\hline
\end{tabular}


Bankaların kurumsal sürdürülebilirlik raporlarında en az finansal sürdürülebilirlik boyutunda açıklama yaptıkları görülmektedir. Kamu bankalarında, finansal sürdürülebillirlik boyutundaki açıklamalar toplam açılamaların \% 3,46'sını oluştururken, özel bankalarda ise nispeten daha düşük bir yüzde ile \% 3,4'ünü oluşturduğu görülmektedir. Kurumsal sürdürülebilirlik raporlarında en az açıklamaya sahip olan boyutun, finansal sürdürülebilirlik boyutu olmasının nedeni olarak bu göstergelerin halihazırda finansal tablo ve dipnotlarda yatırımcı ile paylaşımış olduğunun düşünülmesidir. Oysa burada diğer boyutlardaki gelişmelerin finansal sonuçlarla ilişkisinin gösterilmiş olması beklenmektedir. Finansal sürdürülebilirlik göstergelerinde özel bankaların en çok açıklama yaptıkları ilk üç göstergenin sırasıyla Kredi Portföyü Hakkında Bilgi, Fon Toplama ile ilgili Bilgiler ve Sermaye Yapısı olduğu belirlenmiştir. Akbank, Garanti ve TSKB nin kredi portföyü hakkında diğer bankalara göre yatırımcılarını daha çok bilgilendirdiklerini söylemek mümkündür. Kamu bankalarında ise Fon Toplama ile ilgili Bilgiler, Sermaye Yapısı ve Geçmiş Yıllara göre Finansal Büyüme kriterlerinde en çok açıklamanın yer aldığı görülmektedir. Garanti ve Yapı Kredi Bankası'nın ilgili dönemde Kar Payı Politikaları konusunda hiç açıklama yapmadığı, kamu bankalarının ise en az bir açıklama yaptığı görülmektedir.

Enerji Tüketimi ve Tasarrufu ile Doğal Çevre konusunda açıklamaların yer aldığı çevresel sürdürülebilirlik boyutunda, her iki alt boyutta da kamu bankalarının, özel bankalara göre açıklamalarının toplam açıklamalar içindeki yüzdesinin daha yüksek olduğu görülmüştür. Özellikle Ürün ve Hizmetlerin Çevresel Etkilerini Azaltmaya Yönelik Girişimler, Kurumsal Çevre Politikaları ve Enerji Kullanımı Verimliliği kriterlerinde en çok açıklama yapıldığı görülmektedir. En az açıklama yapılan kriterlerin ise Çevreyi Güzelleştirme Faaliyetleri, Yeşil Projeler için Düşük Faiz Oranları ve Çevre Dostu Faaliyetlere Yapılan Yardımlar olduğu içerik analizi sonucunda belirlenmiştir. Özel bankalarda ise, Sera Gazı Salınımını Azaltma Girişimleri, Ürün ve Hizmetlerin Çevresel Etkilerini Azaltmaya Yönelik Girişimler ve Kurumsal Çevre Politikaları en çok açıklama yapılan kriterler olduğu görülmektedir. Özellikle, Garanti Bankası ve TSKB'nin sürdürülebilirlik raporlarında bu konularda diğer bankalara göre daha çok açıklama yaptıkları analiz edilmiştir. Kamu bankalarında benzer şekilde Yeşil Projeler için Düşük Faiz Oranları açıklamaları konusunda az açıklama yapıldığı, özel bankalarda ise sadece Garanti Bankası ve İşbankası'nın bu konuda açıklama yaptığı görülmektedir.
İçerik analizi sonucunda, ilgili dönemde, Türk Bankacılık Sisteminde yer alan kamu ve özel bankaların kurumsal sürdürülebilirlik göstergelerinin, yaklaşık $\%$ 50'sinin sosyal sürdürülebilirlik açıklamalarından oluştuğunu söylemek mümkündür. Bu durum, bankacılık sektörünün sosyal farkındalık konularına önem verdiğini göstermektedir. Topluma Katkı, İnsan Kaynakları, İnsan Hakları ve Ürün Sorumluluğu hakkında açıklamaların yer aldığı Sosyal Sürdürülebilirlik Boyutunda, kamu bankalarının, özel bankalara göre yaptığı açıklamalarının toplam açıklamalar içindeki yüzdesinin daha yüksek olduğu görülmüştür. Sadece Insan Kaynakları açıklamalarının, özel bankalarda kamu bankalarına göre toplam açıklamalar içindeki payının daha yüksek olduğu söylenebilir.

Kamu Bankalarının, topluma katkı açıklamaları içinde Kırsal Kesimler için Kalkınma Programları ve KOBi'lerin Desteklenmesi ve Finanse Edilmesi göstergeleri en çok açıklanan göstergeler arasında yer alırken, Ürünler ve Hizmetler Hakkında Bilgilendirme, Müşteri Memnuniyetinin Sağlanması, İnsan Kaynakları Planlaması ve Politikaları diğer çok açıklanan kriterler arasında görülmektedir. Özel bankalarda ise Kurumsal Sosyal Sorumluluk Faaliyetlerinin Katkısı ve bu Faaliyetlerine Verilen Önem, Toplumsal Farkındalık Faaliyetleri ve Kültür-sanat Alanında Yapılan Yatırımlar Hakkında Bilgi, topluma katkı alt başlığı altında en çok açıklanan göstergeleri oluşturmaktadır. Özellikle Müşteri Memnuniyetinin Sağlanması, Ürün ve Hizmetler Hakkında Bilgilendirme, Insan Kaynakları Planlaması ve Politikası diğer çok açıklanan kriterler arasında görülmektedir.

Dini Faaliyetlerin Gerçekleştirilebilmesi için İmkan Sunulması, Mağdur Olan Kadınlara Çeyiz Yardımı, Kırsal Kesimde Yaşayanlar için Ücretsiz Sağlık Sigortası, Yoksullar için Sağlık Tesisleri, ihtiyat Fonu ile Illgili Bilgi ise her iki grupta ilgili dönemde hiç açıklanmayan kriterlerdir.

Toplam açıklamalar içindeki payı en yüksek olan ikinci kurumsal sürdürülebilirlik boyutunun ise kamu ve özel bankalar için yönetsel göstergeler olduğu görülmektedir. Bu göstergelerde, özel bankaların, kamu bankalarına göre açıklamalarının toplam açıklamalar içindeki yüzdesinin daha yüksek olduğu görülmüştür. Sürdürülebilir Kalkınma için Kurumsal Politika ve Stratejiler, Kurumsal Yönetim ve Uygulamaları kriterlerinin her iki grup için de en çok açıklanan kriterler olduğunu söylemek mümkündür. Özel bankalar arasında özellikle TSKB'nin bu göstergeler içinde en çok açıklama yapan banka olduğu görülmektedir. 
Bu sonuçlar kamu bankalarının özel bankalara göre toplumsal fayda, sosyal etki ve çevresel sürdürülebilirlik açısından daha fonksiyonel olduğunu ifade etmekte, yönetsel olarak ve kurumsal yönetim ilkeleri çerçevesinde özel bankaların kamu bankalarına göre daha etkin olduğu gözlemlenmektedir.

\section{SONUÇ}

Kurumsal sürdürülebilirlik, "stratejik bir yaklaşım" olarak, ekonomik, çevresel ve sosyal açıdan etkin risk yönetim altyapısı oluşturarak, uzun dönemde firma ve yatırımcılar için getiri sağlayabilecek bir hedeftir. Kurumsal düzeyde sürdürülebilir firmalar, strateji ve yönetim tarzlarını geliştirerek, sürdürülebilir ürünlere veya hizmetlere ulaşırken, aynı zamanda iş süreçlerinde giderlerini ve risklerini de en iyi şekilde yönetebilen firmalardır. Finansal sistemin içinde bulunan bütün kurumların sağlıklı ve etkin çalışması bu kurumların reel sektörü ve ekonomiyi doğrudan etkilemesi açısından ayrıca önem taşımaktadır. Zira finansal sistemin temelini oluşturan bankaların kullandırdığı krediler yoluyla yapılan yatırımlar ve diğer finansal ürünler, doğrudan ve dolaylı yollarla çevreye, ekonomiye ve sosyal hayata etki etmektedir. Bu nedenle bankaların sürdürülebilir yatırımları finanse etmek ve müşterilerini de bu konuda bilinçlendirmek konusunda duyarlılıkları ve sürdürülebilirlik performanslarının değerlenmesi ve izlenmesi buyuk önem kazanmıştır. Bu çerçevede, Türk Bankacılık Sektörü'nde bu yöndeki çalışmaların başlangıcından günümüze kadar gelişimi, kurumsal sürdürülebilirlik kriterleri açısından analiz edilerek değerlendirilmesi daha önce literatürde bulunmaması açısından da son derece önemlidir.

Bununla birlikte, global gelişmeler ve yaşanan finansal krizler kurumsal sürdürülebilirliğin temel göstergeleri olan ekonomik, sosyal ve çevresel faktörlerin şirketlerin performanslarını ölçmek için yeterli olmadığını göstermiştir. Bu göstergeler ile birlikte, iyi bir yönetsel yapı, kurumsal yönetim uygulamalarının varlığı ve finansal göstergelerin sağlamlığı, kurumsal sürdürülebilirliği tamamlayan faktörler olarak önem taşımaktadır. Bu durum, temel sürdürülebilirlik faktörlerinin yanında yönetsel ve finansal faktörlerin de firmaların sürdürülebilirlik performansının ölçümünde dikkate alınmasını gerekli hale getirmiştir.

Bu çalışma, kurumsal sürdürülebilirliği ekonomik, sosyal, çevresel, yönetsel ve finansal olmak üzere beş boyut ile kapsamlı olarak değerleyen ilk özgün çalışma özelliği taşımaktadır. Önerilen çok boyutlu kurumsal sürdürülebilirlik modeli çerçevesinde, Türk Bankacılık Sektöründe yayınlanan sürdürülebilirlik raporları içerik analizi yöntemiyle incelenerek sürdürülebilirlik göstergelerinin değerlemesi kamu-özel banka farklılaşması ortaya konulmaktadır.

Iç̧erik analizi sonucunda, bankaların sürdürülebilirliğin beş boyutuna yönelik yaptıkları açıklamaların ağırlıklı olarak sosyal sürdürülebilirlik boyutunda yoğunlaştığı ve kamu bankalarının özel bankalara göre, sosyal açıklamalara daha fazla ağırlık verdiği görülmektedir. Kamu ve özel bankaların kurumsal sürdürülebilirlik boyutları arasında sosyal sürdürülebilirlik açıklamalarının ağırlıkı olması, bir anlamda bankaların sosyal etkiye yönelik duyarlıııkarının yüksek olduğunun, kamu bankalarının bu açıdan daha etkin olabildiklerinin işaretidir. Kamu bankalarında aynı zamanda çevresel sürdürülebilirlik boyutunda ve topluma katkı ile ürün sorumluluğu alanındaki açıklamaların toplam sürdürülebilirlik açıklamaları içindeki oran özel bankalara göre daha yüksektir. Toplam açıklamalar içinde en düşük orana sahip olan boyutlar ise ekonomik ve finansal sürdürülebilirlik boyutlarıdır. Yönetsel açıklama oranının özellikle kamu bankalarında daha az olması dikkati çeken bir diğer bulgu olarak karşımıza çıkmaktadır.

Bankaların dönemsel açıklama etkinliğine bakıldığında ise, 2014 yılında diğer yıllara göre, sektörde yer alan tüm kurumsal sürdürülebilirlik raporlarında beş boyutu temsil eden göstergelerin daha etkin yer aldığı görülmektedir. İlgili dönemde raporların, GRI G4 raporlama ilkelerine göre hazırlanmaya başlanması sürdürülebilirlik açıklamalarının daha kapsamlı olmasının nedenleri arasındadır. Bu alanda uluslararası ilke ve standartların gelişmesi, kurumları daha şeffaf olmaya yönlendirdiği görülmektedir.

Sürdürülebilir bankacılık uygulamalarının gelişmesi için gönüllülük esasına bırakılan uygulamaların yasa ve ilkelerle düzenlenmesinin başlangıçta sürecin gelişimine katkı sağladığını diğer ülke uygulamalarından görmek mümkündür. Buna ilave olarak sürdürülebilir kalkınma politikalarının geliştirilmesi ve uygulanması son derece önemlidir. Aynı zamanda finansal kuruluşların ve bütün paydaşlarının sürdürülebilirlik konusunda bilinçlendirilmesi bu alandaki gelişmeleri önemli ölçüde hızlandıracak ve etkinleştirecektir. Bu süreçte kamu bankalarının kapsayıcılığı ve kamusal sorumluluklarından kaynaklanan duyarlılıkları nedeniyle, sürdürülebilirlik alanında öncü olması beklenmektedir. 
Kurumsal sürdürülebilirlik ölçümü ve değerlemesi hem dünya da hem de Türkiye'de üzerinde önemle durulması ve çalışılması gereken bir alandır. Özellikle Türkiye'de firmaların bütün iş süreçlerinde finansal performans ile birlikte işletmenin çevresel ve sosyal risklerini iyi yönetmesinin gereğini ve önemini anlamaları gerekmektedir. Bunun sonucu olarak sürdürülebilirlik uygulamalarına daha fazla önem vermeye başlamaları, aynı zamanda akademik çalışmalar için de nitelikli verilerin oluşmasına yardımcı olmaktadır. Bu durum ileride bu konuda daha kapsamlı ve nitelikli çalışmaların yapıımasını sağlayacaktır. Öte yandan, ozellikle sürdürülebilirlik performansının ölçümü için nitelikli verinin elde edilmesinin ve işlenmesinin zorluğu ve yapılacak ölçüm ve değerlemenin nitelikli metodolojik yaklaşım gerektirmesi bu alanda üretilen her özgün çalışmayı daha da önemli hale getirmektedir.

\section{SON NOTLAR}

'Halkbank 2013 yılı Sürdürülebilirlik Raporu, 2015 yılında yayınlandığı için araştırma kapsamına alınamamıştır. 2illgili raporlar, 2015 yılı ikinci çeyrekte yayınlandığı için araştırma kapsamına alınamamıştır.

${ }^{3}$ Kurumsal sürdürülebilirlik raporunun GRI kılavuzuna göre hazırlanmadığını ifade etmektedir.

\section{KAYNAKLAR}

Aras, G. 2015. Sustainable Markets for Sustainable Business: Global Perspective for Business and Financial Markets, Routledge Publishing, UK

Aras, G. ve Crowther, D. (2009), "Making Sustainable Development Sustainable", Management Decision, 47( 6): 975-988.

Aras G. ve Crowther D. (2009a), "Corporate Sustainability Reporting: A Study in Disingenuity?", Journal of Business Ethics, 87: 279-288.

Bilgin, N. (2001), Sosyal Bilimlerde İçerik Analizi: Teknikler ve Örnek Çalışmalar, Siyasal Kitabevi, İstanbul.

Birleşmiş Milletler Küresel ìlkeler Sözleşmesi, http:// www.globalcompactturkiye.org/ (16.06.2016).

Elkington, J. (1997). Cannibals with Forks:Triple Bottom Line of 21st Century Business. Chichester UK: Capstone Publishing Limited.

GRI (2013), Sustainability Reporting Guidelines, Global Reporting Initiatives Guidebook.

Hackston, D. ve Milne, M.J. (1996), “Some Determinants of Social and Environmental Disclosures in New Zealand Companies", Accounting, Auditing \& Accountability Journal, 9(1), 77-108.

Hussain, N, Ugo R ve Rene' P. Orij. (2016) "Corporate Governance and Sustainability Performance: Analysis of Triple Bottom Line Performance", Journal of Business Ethics. 25: 1-22.

Jeucken, M. H., ve Bouma, J. J. (1999). "The Changing Environment of Banks", Greener Management International, 27: 20-35.

Jeucken, M. (2001). “Sustainable Finance and Banking - Slow Starters are Gaining Pace", Working Paper Series, Sustainability in Finance:1-7.
Kaderli, Y. Gündüz, Ç. (2014), "Sürdürülebilirlik ve Firma Performansı: BíST 100 Banka Endeksi Üzerine Bir Uyugulama" 18. Finans Sempozyumu Pamukkale Üniversitesi Bildiriler Kitabı.:607-625.

Kaya, E.Ö. (2010), "Sürdürülebilir Kalkınma Sürecinde Bankaların Rolü ve Türkiye'de Sürdürülebilir Bankacılık Uygulamaları", İşletme Araştırmaları Dergisi, 2(3): 75-94.

Khan, Md.H., Islam M.A., Fatima J.K. ve Ahmed K. (2011), "Corporate Sustainability Reporting of Major Commercial Banks in line with GRI: Bangladesh Evidence", Social Responsibility Journal, 7(3): 347-352.

Krippendorff, K. (2004), Content Analysis: An Introduction to its Methodology, Sage Publications, London.

Milne, M.J. ve Adler, R.W. (1999), "Exploring the Reliability of Social and Environmental Disclosures Content Analysis", Accounting, Auditing \& Accountability Journal, 12(2): 237-256.

Moneva, J., Juana M. Rivera-lirio, M. J.Munoz-torres. (2007), "The Corporate Stakeholder Commitment and Social and Financial Performance". Industrial Management \& Data System, 107(1): 84-102.

Ng, L.W. (1985), "Social Responsibility Disclosures of Selected New Zealand Companies for 1981, 1982 and 1983", Occasional Paper, No. 54, Massey University, Palmerston North.

Nobanee H. ve Ellili S. (2016), “Corporate Sustainability Disclosure in Annual Reports: Evidence from UAE Banks: Islamic versus Conventional", Renewable and Sustainable Energy Reviews, 55: 1336-1341.

Özçelik, F. ve Öztürk, B.C.. (2014), “Evaluation of Banks' Sustainability Performance in Turkey with Grey Relation Analysis". Muhasebe ve Finansman Dergisi: 189-209. 
Özyurt, H., Tandoğan D. (2013), “Bankacılık Sektörünün Ekonomik Büyüme ve Sürdürülebilir Ekonomik Kalkınma Üzerine Etkisi: Türkiye Ekonomisi Üzerine Nedensellik Testleri (1981-2009). Marmara Üniversitesi Iktisadi ve Idari Bilimler Fakültesi Dergisi, 35(2): 49-80.

Ranganathan, J.(1998), "Sustainability Rulers: Measuring Corporate Environmental and Social Performance". Sustainable Enterprise Initiative, 1(12).

Sobhani, F.A., Amran, A., Zainuddin, Y. (2012), "Sustainability Disclosure in Annual Reports and Websites: A Study of Banking Industry in Bangladesh", Journal of Cleaner Production, 23: 75-85.

Sobhani, F. A., Amran A., Zainuddin,Y. (2009), Revisiting the Practices of Corporate Social and Environmental Disclosure in Bangladesh, Corporate Social Responsibility and Environmental Management, 16:167-183.

WCED, 1987, "Our common future" (The Brundtland Report), Oxford University Press

Weber, R.P. (1990), Basic Content Analysis, Sage, Newbury Park, CA.

\section{Kurumsal Sürdürülebilirlik Raporları}

Akbank Kurumsal Sürdürülebilirlik Raporları (20092014). http://www.akbank.com/tr-tr/Yatirimci-iliskileri/ Sayfalar/Surdurulebilirlik-Raporu.aspx, (10.04.2016).

Garanti Bankası Kurumsal Sürdürülebilirlik Raporları (2010,2011-2012,2013,2014,2015, http://www. garanti.com.tr/tr/garanti_hakkinda/surdurulebilirlik/ surdurulebilirlik_gelismeleri/raporlar.page, (17.03.2016).
İşbankası Kurumsal Sürdürülebilirlik Raporu $(2012,2013,2014) \quad$ http://www.isbank.com.tr/TR/ hakkimizda/surdurulebilirlik/raporlarimiz/Sayfalar/ raporlarimiz.aspx

Şekerbank Kurumsal Sürdürülebilirlik Raporu (2013), http://www.sekerbank.com.tr/hakkimizda/ surdurulebilir/surdurulebilirlik-raporu (17.03.2016).

Türkiye Finans Bankası Kurumsal Sürdürülebilirlik Raporu (2013), https://www.turkiyefinans.com.tr/ tr-tr/hakkimizda/surdurulebilirlikraporumuz/files/ TF2013sur.pdf, (15.02.2016).

TSKB Kurumsal Sürdürülebilirlik Raporları (2008-2009, 2009-2010, 2011-2012, 2013-2014), http://www. tskb.com.tr/tr/surdurulebilir-bankacilik/tskb-desurdurulebilirlik/surdurulebilirlik-raporlari (15.04.2016). Vakıfbank Kurumsal Sürdürülebilirlik Raporu (2015), http://www.vakifbank.com.tr/surdurulebilirlikraporlari.aspx?pagelD=1254 (10.05.2016).

Yapı ve Kredi Bankası Kurumsal Sürdürülebilirlik Raporları $(2010,2011,2012,2013,2014)$, https://www. yapikredi.com.tr/yapi-kredi-hakkinda/kurumsalsosyal-sorumluluk/surdurulebilirlik-raporlari.aspx, (12.05.2016).

Ziraat Bankası Kurumsal Sürdürülebilirlik Raporları $\quad(2013,2014) \quad$ http://www.ziraatbank. com.tr/tr/Bankamiz/Surdurulebilirlik/Pages/ SurdurulebilirlikRaporlari.aspx (15.06.2016).

\section{Ek: Bankacılık Sektörü Kurumsal Sürdürülebilirlik Göstergeleri Kriter Listesi}

GRI Raporlama Çerçevesi, literatür taraması sonuçları (Sobhani, 2012: 83-85) ve üst düzey yöneticiler ile gerçekleştirilen mülakatlar sonucunda, Türk Bankacılık Sektörü'ne özgü, Ekonomik- Finansal Çevresel-SosyalYönetsel olmak üzere 5 boyutu temsil eden toplamda 139 Kurumsal Sürdürülebilirlik kriteri belirlenmiştir.

\begin{tabular}{|l|}
\hline EKONOMIK GÖSTERGELER \\
\hline Dağıtılmayan Karlar Hakkında Bilgi \\
\hline Sermaye Sahiplerine Yapılan Ödemeler \\
\hline Ulusal Hazineye Katkısı \\
\hline Kurumsal Sosyal Sorumluluk ve Sürdürülebilirlik Çalışmalarına Harcanan Miktar \\
\hline Altyapısal ve Kurumsal Gelişim \\
\hline Yerli Ekonomideki Yeri \\
\hline Küresel Ekonominin Etkisi \& Küresek Ekonomideki Yeri \\
\hline Ekonomik Katkı Raporu \\
\hline Diğer Ekonomi Açıklamaları \\
\hline FiNANSAL GÖSTERGELER \\
\hline Sermaye Yapısı \\
\hline Kar Payı Politikaları \\
\hline
\end{tabular}


Fon Toplama ile İlgili Bilgiler

Geçmiş Yıllara Göre Finansal Büyüme

Kurumsal Finansal Performans Yorumu

Kredi Portföyü Hakkında Bilgi

\section{ÇEVRESEL GÖSTERGELER}

Enerji Tüketimi ve Tasarrufu Açıklamaları

Enerji Tasarrufu Politikaları

Enerji Projeleri Yatırımları

Yenilenebilir Enerji Yatırımları

Enerji Tüketimi Hakkında Bilgi

Enerji Tüketimini Azaltmaya Yönelik Girişimler

Enerji Tüketimi Hakkında Farkındalık Yaratma

Enerji Kullanımı Verimliliği

Enerji Tasarrufu Sonuçları

Diğer Enerji Açıklamaları

Doğal Çevre Açıklamaları

Kurumsal Çevre Politikaları

Çevreyi Koruma Gerekliliği

Çevre Yönetmeliğine Uyum

Atıkların Geridönüşümü \& Arıtma Tesisi için Yapılan Yatırımlar

Su Temini ve Sağlık Önlemleri Hakkında Yapılan Girişimler

Çevresel Finansman (Örn; Ekolojik Krediler) \& Yenilenebilir Enerji Finansmanı

Yeşil Projeler için Düşük Faiz Oranları

Çevre Dostu Faaliyetlere Yapılan Yardımlar

Temiz Bir Çevre İçin Gerekli Adımların Oluşturulması

Ağaçlandırma Faaliyetleri

Çevreyi Güzelleştirme Faaliyetleri

Sera Gazı Salınımını Azaltma Girişimleri

Ürün ve Hizmetlerin Çevresel Etkilerini Azaltmaya Yönelik Girişimler

İklim Değişikli Hakkında Bildirimler

Diğer Çevresel Açıklamalar

Su Tüketimi Hakkında Bilgi

Kağıt Tüketimi Hakkında Bilgi

Karbondioksit Tüketimi Hakkında Bilgi

\section{SOSYAL GÖSTERGELER}

Topluma Katkı Açıklamaları

Toplumsal Yapının Gelişimi için Taahhütte Bulunma

Toplumun Gelişimine Verilen Önem

CSR Faaliyetlerinin Katkısı \& CSR Faaliyetlerine Verilen Önem

Kobilerin Desteklenmesi ve Finanse Edilmesi

Yoksullukla Mücadele Programları

Kırsal Kesimler için Kalkınma Programları

Kadın Girişimciler için Kredi İmkanları

Yoksul Kadın ve Çocuklara Finansal Destek

Mağdur Olan Kadınlara Çeyiz Yardımı

Engelli ve Yaşı İnsanlara Yardım 


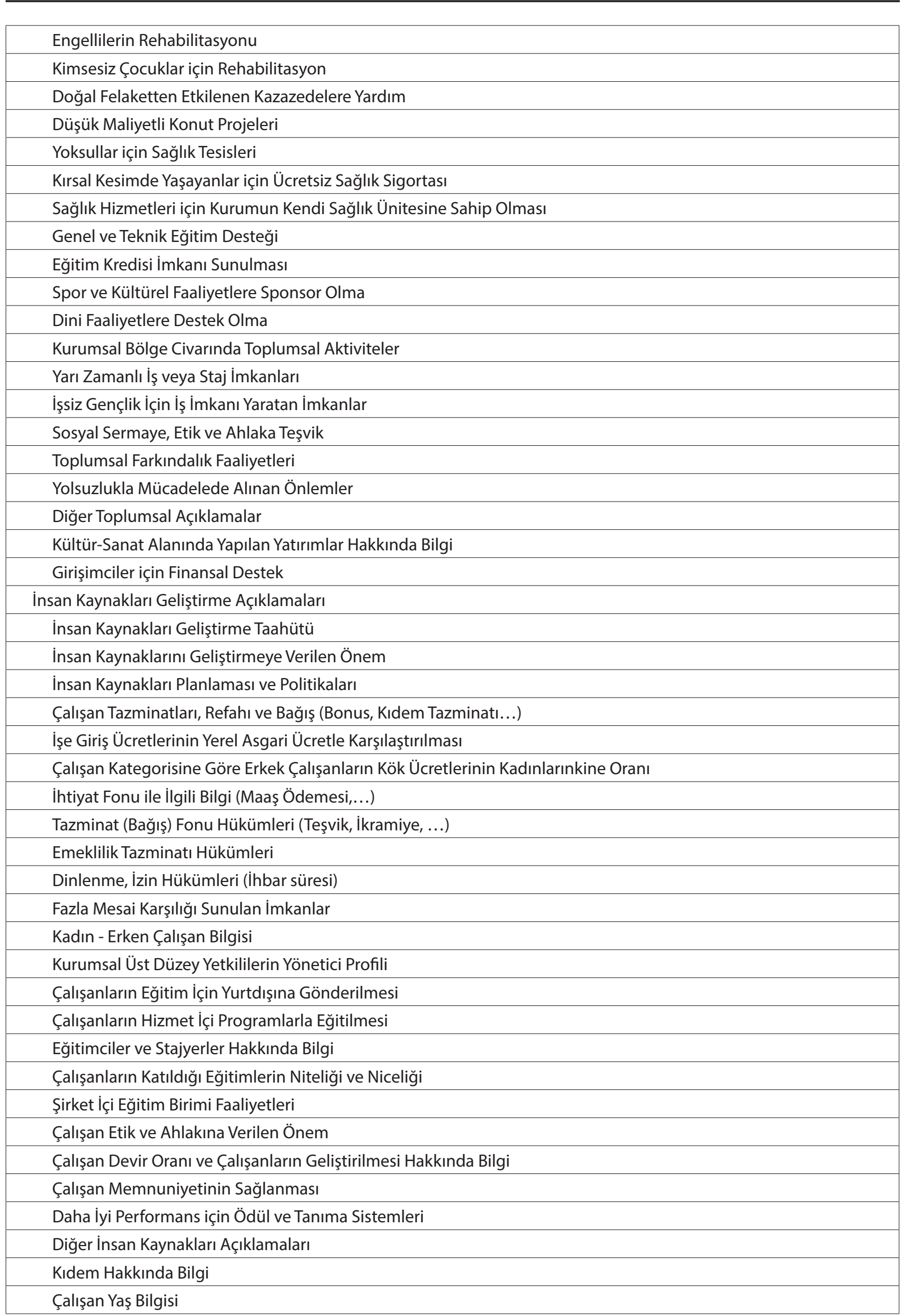




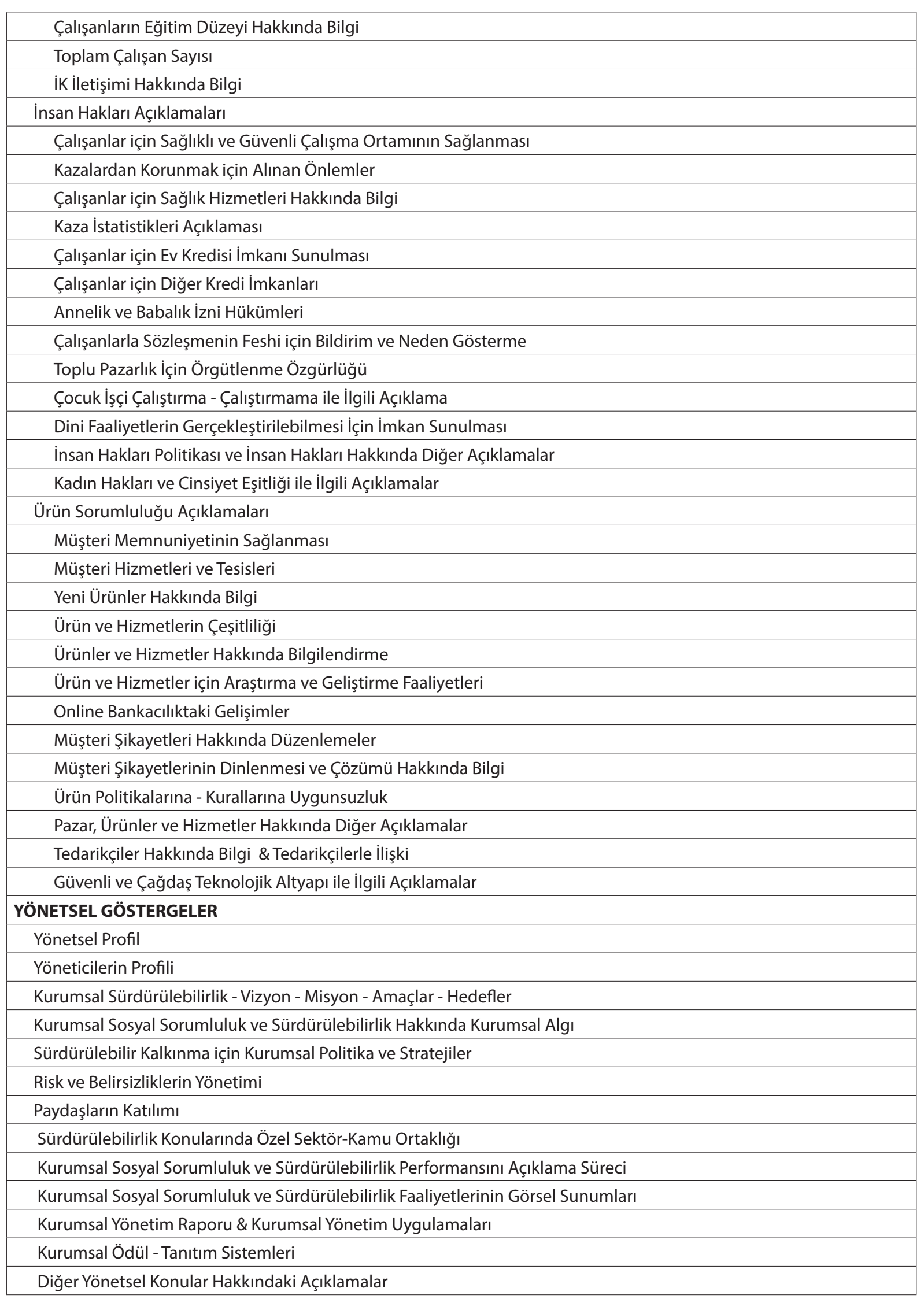


